\title{
The nominative and propositive structures of the word
}

\section{Raxima KURBANOVA ${ }^{1}$}

Samarkand State Medical Institute

\begin{tabular}{l} 
ARTICLE INFO \\
\hline Article history: \\
Received March 2021 \\
Received in revised form \\
20 March 2021 \\
Accepted 15 April 2021 \\
Available online \\
20 May 2021
\end{tabular}

Keywords:

nomninative,

propositive,

words structure,

derivation.

\begin{abstract}
The central unit of the language is the nominative meaning of the word, which has been thoroughly studied by the present time of the development of the linguistic science and had fundamental research in this area. However, the study of the nominative meaning of syntactic structures in recent years has also begun to be included in the research agenda, and today it has become a special syntactic problem.

2181-1415/C 2021 in Science LLC.

This is an open access article under the Attribution 4.0 International (CC BY 4.0) license (https://creativecommons.org/licenses/by/4.0/deed.ru)
\end{abstract}

\section{So'zning nominativ va ta'sirli tuzilmalari}

Kalit so'zlar:

nominativ,

propozitiv,

so'zlar tarkibi,

hosil qilish.

\section{ANNOTATSIYA}

Tilning markaziy birligi bu lingvistik ilm-fan taraqqiyotining hozirgi davri tomonidan chuqur o'rganilgan va bu sohada fundamental tadqiqotlarga ega bo'lgan so'zning nominativ ma'nosidir. Biroq, so'nggi yillarda sintaktik tuzilmalarning nominativ ma'nosini o'rganish ham tadqiqot kun tartibiga kiritila boshlandi va bugungi kunda bu maxsus sintaktik muammoga aylandi.

\section{Номинативные и влияющие структуры слова}

\author{
Ключевые слова: \\ номинатив, \\ пропозитив, \\ структура слов, \\ вывод.
}

АННОТАЦИЯ

Центральной единицей языка является номинативное значение слова, которое к настоящему времени развития лингвистической науки было досконально изучено и имело фундаментальные исследования в этой области. Однако изучение именительного падежа синтаксических структур в последние годы также стало включаться в повестку дня исследований и сегодня это стало особой синтаксической проблемой.

\footnotetext{
${ }^{1}$ Lecturer of Samarkand State Medical Institute, Samarkand, Uzbekistan.
} 
It is noteworthy that syntactic structures, in particular, the nominative character of the word, show that there is a significant difference between the nominative features of the word and a sentence. Firstly, a word is literally a nominative unit, and therefore maintains its status in the speech and in the vocabulary of the language. The sentence is temporal in this aspect. It can only express a real nominative meaning when used in speech. Secondly, the fact that the word is a nominative unity is also clearly seen in the context of the denotation, which is reflected in the form of a specific narrative expressed through it. In other words, the expression of the word (signifier) is a pure sign, and the expression of the statement is a sign that also comes in the status of a denotation. Thirdly, the word is often polysemantic, and the sentence is monosemantic. Fourthly, if the word is a nominative unit, then this is the case once in a lifetime [1].

The nominative mark of the speech is in close contact with its propositional structure. The concept of "proposition" plays an important role, because the proposition is the center of the meaning of the word.

It should be noted that the nominative and propositive structures of the word are closely related to the illogical plan of the speaker. It also has a strong impact on the perlocutative plan, which is based on the acceptance of the listener's message. Most of the issues mentioned above are still in linguistics and these problems, in particular, have not been literally investigated in terms of systemic interpretation of language units. Based on these, it is possible to argue the relevance of the topic selected for the article [2-5].

The main purpose of this paper is to investigate the lexical and propositive characteristics of the syntactic structures on the basis of the relationships and to give them a scientific interpretation of their related issues.

Research tasks:

- studying the communicative process and its communicative state, and focusing on the derivative characteristics of the speech units;

- studying the process of nuances related to a specific situation and the formation of a nominative meaning in this situation;

- To give a comparative interpretation of the lexical and propositional nominations;

We know that any sentence serves to name certain reality and informs about it. To express reality events in the form of a sentence, it is necessary to choose the correct syntactic structures, and this requires the right choice and nominative units in the status of the word. That is, in this case, the reserve of ready nominative units of the speaker acquires great importance.

Although all the nominative units (noun, adjective, verb, participle) are similar to each other in that they express a certain concept, but each of them sharply differs from each other [6] The structure of linguistic activity manifests itself in acts of naming, where the instrument is speech sounds, and material - naming objects (things real or imaginary). It should be noted that there is no a complete identity between a naming and an object. In other words, the relationship between the denotation and the signifier is not always constant and stable. Since in the process of speech the significant can both approach the denotation, and move away from it. For example, stout, fat people are compared to a bear, and strong ones to a tiger. In such cases, the relationship between the denotation and the signifier becomes abstract. 
A harmonious connection between the denotation and the signifier arises when the nominative unit is expressed by a noun. And in other words, acting in the status of a nominative unit, the connection between the denotation and the signifier is somewhat abstracted. Take, for example, the words road, house, stone, to walk, to sit, to swim. In the words road, house, stone, the objective expression manifests itself clearly. However, in the words to walk, to sit, to swim, although the action, the event is expressed clearly, but at the same time it is clear that the meaning of the denotation is abstract. Of course, derived words are nominative units that exist in the vocabulary of our language, but in their linguistic nature, they are sharply different from non-derivative words [7].

In descriptive linguistics one can find opinions about the similarity of internal structures of complex words and phrases, as well as suggestions. But the very concept of a complex word is not abolished. For example: a chimney sweeper - he sweeps chimneys he cleans the pipes; The man refused to chair the session - the man's refusal to chair the session.

The founder of logical semantics G. Frege gave a fairly convincing interpretation of the notion of nominative content. He introduced the lexical nomination into the research agenda first, then the question of the need to consider the proposal as a nominative unit. The concepts of denotation and reference were also first used by this scientist [8].

The proposition is determined based on the number of arguments of the relational predicate: I returned the book to my brother; my brother received a book from me; the book was returned to me by my brother. Here there is a three-argument or three-place predicate: "return - get back - be returned". Prior to the actualization of the arguments, the predicate is only a "propositional function", an abstract possibility of proposition [9].

The nominative meaning is definitely based on proposition. Therefore, the concept of propositional nomination is widely used lately. The concept of propositional nomination is not only important for semantic learning of syntactic structures but also language phenomena. The fact that there is a certain situation behind the proposal requires a nominative event, and a situation always has a proposition behind it. This is the basis of the propositive nomination: 1 . The rain dripped from the palm trees (0. Henri) - It was raining from the palm leaves. - After a second our door opened and a young man of high stature entered the room.

In the first of the above sentences, we see a single proposition (because of the limited structure), so the situation and the sentence can be considered as an isomorphic phenomenon. Of course, this should be understood relatively, since the situation is behind the proposal and can become completely isomorphic event only with respect to the proposal. In the second sentence, because of the existence of two propositions, the situation and the proposal cannot become isomorphic events [10].

Thus, we can speak of a nominative meaning only when the syntactic structure requires a phrase or sentence. However, the situation can only be related to a sentence or a larger syntactic unit. And the situation can not arise without the participation of the human factor.

Conclusion

However, it should be noted that the lexical nomination event is formed within the specific meaning of a particular word. The concept presented through the identity is relative abstract. This abstract moves to a specific expression when used realistically in speech. It should be also noted that the actual meaning of the word is always kept. Additional characters added in the talk cannot change the true meaning of the word. 


\section{REFERENCES:}

1. Arutyunova N.D. Proposition // Linguistic encyclopedic dictionary. - M.: Soviet encyclopedia, 1990. - P. 682.

2. Frege G. Funktion, Begriff, Bedeutung, Cattingen, 1962. - P. 17.

3. Kashgariy M. Devonu Lugotit Turk. - Tashkent: Fan, 1960. - P. 499.

4. Khodzhiyev A. The system of word formation of Uzbek language. - Tashkent: O’qituvchi, 2007. - P. 166.

5. Kanselson S.D. “Speech cogitative process” // Linguistics questions, 1984, No.6. - P. 4.

6. Kurbyakova E.S.Nominative aspect of speech activity - M.: 1986. - P. 23.

7. Smirnitskiy A.I. Syntax of English language. - M.: Published. Literature of foreign languages, 1957. - P. 286.

8. Rassel B. Logic and Knowledge. - London, 1956. - P. 382.

9. Vigotskiy L.S. "Thinking and speech" Gathered essay - M.: P 11. - PP. 12-13.

10. Amanova N. (2019). Genre and stylistic features of the structure and dynamics of the development of modern Uzbek pop music. Eurasian music science journal, 1(1). PP. 121-137. 